\title{
Japan goes for the sun
}

Tens of thousands of Japanese homes and businesses are preparing to put new solar panels on their roofs, spurred by a subsidy plan going into effect this month. It is a step towards regaining Japan's once-dominant position in solar energy, something that has become a matter of pride for the country's policy-makers.

But the government knows it cannot count on citizens to continue backing solar energy out of civic pride and eco-mindedness alone, so it is now spending $¥ 30$ billion (US $\$ 300$ million) of state money annually on subsidies and research and development on the technology.

In 1999 Japan led the world in solar-cell production, a position it maintained for several years. In 2005, solar cells produced by Japan accounted for $45 \%$ of the world's capacity, according to figures from the country's industry ministry. By 2007 , however, the figure was only $24.6 \%$, barely ahead of China's $22.0 \%$.

Each year from the late 1990s on, Japan also installed more capacity for producing energy from solar cells than any other country, but was surpassed by Germany in 2005 and Spain in 2008. It more than doubled its total capacity between 2003 and 2007, but could not keep pace with Germany's ninefold increase over the same period. The German boom was fuelled by a 'feed-in' tariff which guarantees that solar-cell power plants and rooftop installations receive a high price for electricity that they feed back into the grid. By 2007, Germany had twice Japan's 1.92 gigawatts of installed capacity.

Japan now wants to get back on top. Last July, the cabinet announced a low-carbon-economy action plan that called for the country to "regain its global leadership position in solar generation". It set out ambitious targets to increase its 1.4 gigawatts of solar power capacity in 200520 -fold by 2020. The 2009 budget earmarks $¥ 10$ billion for solarphotovoltaic energy research and development. Another $¥ 60$ billion has been set aside for renewable energy subsidies, a third of which will go

on solar cells.

The country's recently announced economic stimulus package also targets solar research and development as a major investment area, although specific numbers have not yet been determined (Nature 458, 819; 2009).

The subsidy programme starting this month gives $¥ 70,000$ per kilowatt to homes and businesses that install solar panels. So far it is proving popular, with 22,000 applications in its first two-and-a-half months.

Takashi Kawabata of the industry ministry's



new and renewable energy division notes that Japan is unusual in having so much of its capacity - 1.55 million kilowatt-hours, or $80 \%$ - in homes and businesses. In Germany, only $40 \%$ of the country's capacity is found in these places; instead, power companies have found it profitable to invest because of the feed-in tariffs. "Germans do it because it is profitable," Kawabata says, "but there's no profit for the Japanese." To explain his fellow-citizens' motivation for installing the technology, he cites

\section{Basic researchers protest UK budget}

Britain's government has unveiled an economic stimulus package designed to harness what it calls a "world-class science base" - at the same time as it cuts funds for undirected basic research.

In a speech to parliament on 22 April, Alistair Darling, the Chancellor of the Exchequer, unveiled the 2009 budget. It includes $\notin 1.4$ billion (US $\$ 2.1$ billion) in new cash for low-carbon business and technology.

Some scientists were underwhelmed by the plan, which redirects $\notin 106$ million from the nation's seven research councils, which fund most of Britain's basic research, towards "key areas of economic potential". These areas make up roughly $15 \%$ of the councils' $€ 3$-billion annual budget and are defined by five cross-cutting programmes with titles such as "living with environmental change" and "digital "The value of our universities lies in their transformative discoveries."

funding that allows researchers to pursue any topic they choose. Despite the change in focus, Somers argues, the councils will still fund fundamental science: “This has nothing to do with cutting basicresearch funding."

But others see it as an erosion of the councils' economy" (see Nature 453, 11501151; 2008).

Chloë Somers, a spokeswoman for the councils, says that most of the $£ 106$ million will come from reprioritizing the 'blue-skies' based group that advocates for science funding. If it continues, it could undermine the real worth of basic science in Britain, adds Martin Rees, president of the Royal Society. "The value of our universities lies in the transformative discoveries that emerge unpredictably and unplanned," he says. "The research councils should not stifle this potential."

Environmentalists, meanwhile, were cheered by the government's green stimulus package, which includes $\notin 1$ billion to support renewable energy and jobs in green businesses. The development 
